\title{
A Rare Case of Reparative Granuloma of Nasal Cavity
}

\author{
Jadi Lingaiah, Laxminath Ganji, Sailaja Yella, Kranthi Raj Thatikonda \\ Department of Otorhinolaryngology-Head \& Neck Surgery, Chalmeda Anand Rao Institute of Medical \\ Sciences, Karimnagar, India \\ Email: drjadi ms@yahoo.com
}

Received 22 July 2014; revised 20 August 2014; accepted 9 September 2014

Copyright @ 2014 by authors and Scientific Research Publishing Inc.

This work is licensed under the Creative Commons Attribution International License (CC BY).

http://creativecommons.org/licenses/by/4.0/

c) (i) Open Access

\begin{abstract}
Giant cell reparative granuloma (GCRG) is a rare, benign tumour that mostly involves the maxilla and mandible. It is rare in the nasal cavity and paranasal sinuses. Here we report a case of GCRG of nasal cavity in 24-year-old man who came with unilateral nasal obstruction, epistaxis and proptosis. CT scan showed soft tissue hypodensity lesion of left nasal cavity. Endoscopic surgical excision and biopsy were done. The pathology was consistent with GCRG. There was no recurrence seen on follow-up for 2 years. A short literature review about diagnosis, clinical behavior, radiological findings and treatment of this tumor entity are given.
\end{abstract}

\section{Keywords}

\section{Reparative Granuloma, Giant Cell Tumour, Aneurysmal Bone Cyst}

\section{Introduction}

The term giant cell reparative granuloma (GCRG) was first introduced by Jaffe in 1953 [1] and is a benign fibroosseous lesion typically presenting as an expansile mass with cortical bone defect. Although this lesion is most frequently seen in mandible and maxilla, it is also rarely found in nasal cavity, paranasal sinuses, orbit and can also extend intracranially. The etiology of GCRG is uncertain but may be related to an intraosseous haemorrhage following trauma. GCRGs can be observed at all ages, and they tend to appear more often in children and young adults. Despite their benign nature, they may be locally aggressive. In this paper, we report a new case of GCRG originated from nasal cavity with extension into surrounding sinuses and orbit who underwent surgical excision and curettage without any recurrence on follow-up for 2-year period.

\section{Case Report}

A 24-year-old man was admitted to the department of otorhinolaryngology in affiliated hospital with left-sided

How to cite this paper: Lingaiah, J., Ganji, L., Yella, S. and Thatikonda, K.R. (2014) A Rare Case of Reparative Granuloma of Nasal Cavity. International Journal of Otolaryngology and Head \& Neck Surgery, 3, 293-297.

http://dx.doi.org/10.4236/ijohns.2014.35052 
nasal obstruction and epistaxis from 2 months, proptosis and watering from left eye from 15 days. Nasal obstruction was insidious in onset, gradually increasing almost complete obstruction without any diurnal variations. Epistaxis is spontaneous, intermittent, scanty in amount. Proptosis is increasing day by day. He also gives history of pain. No history of nasal discharge, headache, facial trauma or problems with vision or previous nasal surgeries. No significant medical or family history. No cervical lymphadenopathy. On anterior rhinoscopy and nasal endoscopy, a single, smooth, pinkish mass involving middle meatus and middle turbinate is seen (Figure 1). On probing, mass is firm in consistency, insensitive, bleeding on touch. Mild bleeding from the tumour was seen at that time. No extension into nasopharynx is seen on posterior rhinoscopy. Neurological and ophthalmologic examinations were normal, specifically extraocular movements and vision were normal. CT PNS showed soft tissue lesion involving middle turbinate, frontoethmoidal recess, frontal, ethmoid and maxillary sinuses with obliteration and widening of osteomeatal complex. There is erosion of lamina papyracea with extension into left orbital cavity with lateral displacement of medial rectus (Figure 2). Differential diagnosis considered were inverted papilloma, ethmoid malignancy, giant cell tumour. Endoscopic excision and biopsy was done (Figure 3). Histopathologic examination revealed cystic and haemorrhagic areas, fibroinflammatory tissue, multinucleated giant cells and hemosiderin laden histiocytes suggestive of giant cell reparative granuloma (Figure 4). His complaints got relieved after surgery. There was no recurrence seen in 2 years follow-up.

\section{Discussion}

Giant cell reparative granuloma (GCRG) is an uncommon benign lesion involving the mandible and maxilla [1]. It rarely involves orbit, paranasal sinuses, temporal bone, calvaria, long tubular bones [2]-[4]. These are rare benign lesions of controversial pathogenesis, although the most commonly accepted theory is that there is a reactive response to intraosseus haemorrhage secondary to either trauma or chronic inflammation [1] [5]-[7]. In our case, there is no history of trauma or chronic inflammation.

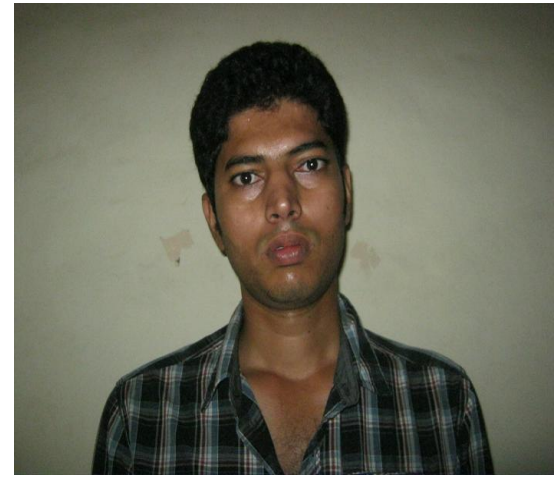

(a)

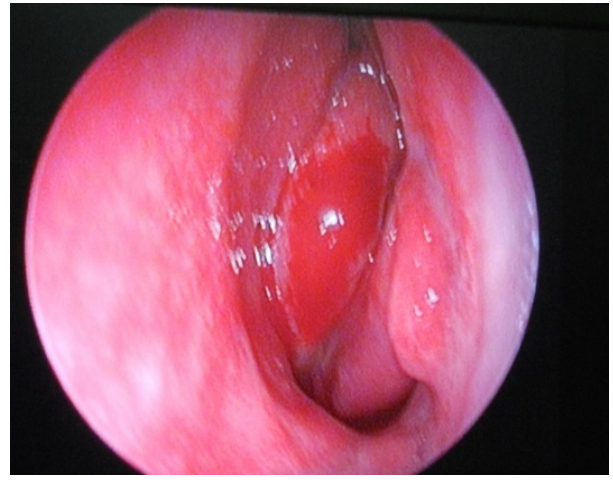

(b)

Figure 1. (a) Patient with proptosis of left eye; (b) Endoscopic picture showing single, smooth, pinkish mass with bleeding in left nasal cavity.
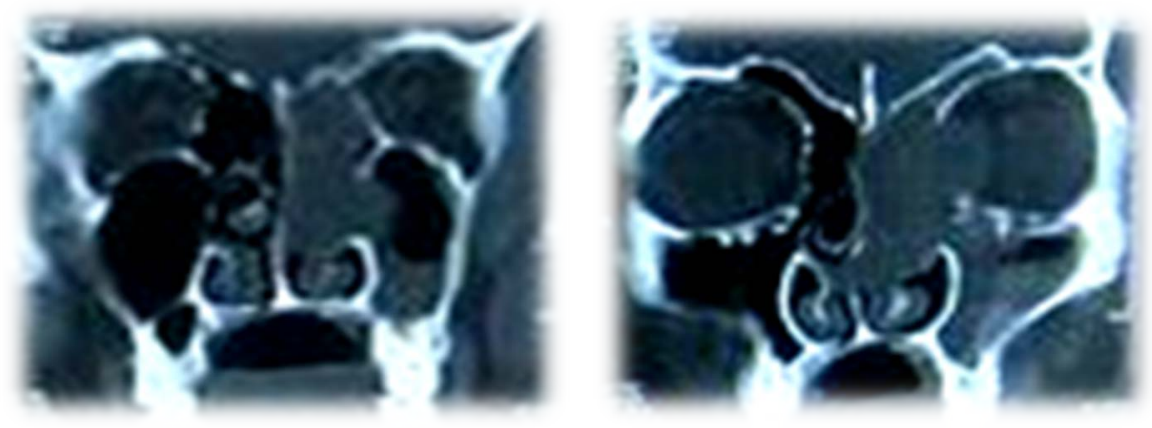

Figure 2. Preoperative computed tomography demonstrates the mass occupied left nasal cavity with erosion of lamina papyracea and extension into the orbit. 


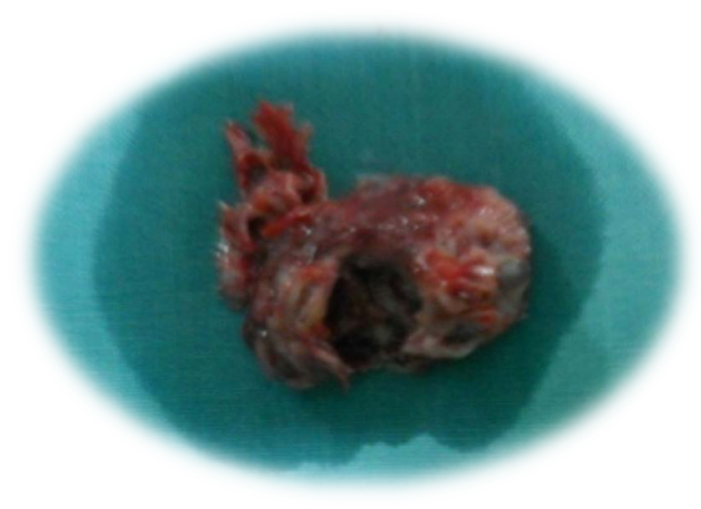

Figure 3. An irregular firm mass of size $5 \times 3 \times 3 \mathrm{~cm}$ is excised completely.

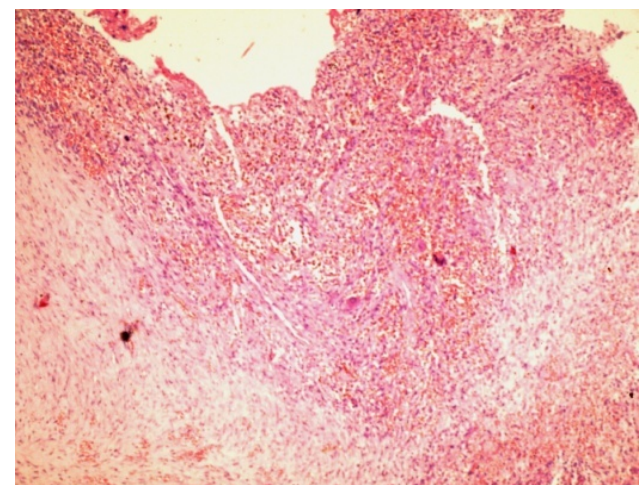

(a)

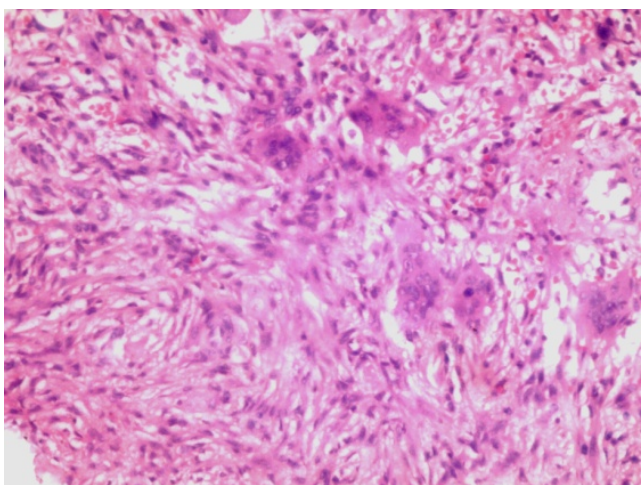

(b)

Figure 4. (a) (Hematoxylin eosin, original magnification $\times 10$ ). Granulomatous tissue with haemorrhagic areas and a large quantity of mononuclear infiltrative cells; (b) (Hematoxylin eosin, original magnification $\times 10$ ). Histopathological examination showed a richly cellular fibroblastic proliferation with multinucleate giant cells interspersed with spindle-shaped stroma.

GCRG has two clinical forms: central-endosteal and peripheral-soft tissue forms. Central type lesions have a bony covering seen in all ages but usually between 10 and 20 years of age. Peripheral lesions are those with a soft tissue component and bony resorption such as those involving the soft tissues of the jaw and gingiva, usually seen in women below 30 years of age. There is no histological difference between central and peripheral giant cell reparative granulomas. GCRG is also divided into two categories according to clinical behavior: aggressive and nonaggressive. Aggressive form lesion is rapidly growing and painful, and in addition recurrence rate is high. Nonaggressive form is more commonly seen with characteristic slow-growth and painless swelling [8] [9]. In our case patient had local pain and proptosis due to erosion of lamina papyracea causing pressure effect of the mass on the orbital soft tissues. So this case was categorized as central and aggressive type.

Radiological findings are relatively nonspecific. An expansile lesion is seen that may perforate the bony cortex occasionally, osteoid is identified within the lesion on CT scan [4]. In our case, there is extension of mass involving frontal, ethmoid, maxillary sinus with erosion of lamina, but areas of calcification or osteoid could not be identified definitely. GCRGs can also appear quite aggressive with bony destruction through either the ethmoid or sphenoid bone, involving the clivus or cribriform plate and extending intracranially or into orbit [5] [6]. MR imaging in this location demonstrates a well circumscribed intraosseous cystic mass with internal haemorrhage and fluid-fluid levels [10].

GCRG of the craniofacial bones has to be distinguished from giant cell tumour (GCT), aneurysmal bone cysts (ABC) and brown tumour of hyperparathyroidism. The usual age of onset of GCTs is in third \& fourth decades. Histologically, GCRG can be difficult to differentiate from GCT. Both show multinucleated giant cells in a connective tissue stroma, in the reparative granuloma however the giant cells are scattered, mitotic figures are 
rare and stromal cells show a cytoplasmic predominance as opposed to those seen in GCT, which show a nuclear predominance [2] [11]. Radiologically, there is evidence of recent and remote haemorrhage in GCRGs with new osteoid formation, whereas in GCT there is limited fresh haemorrhage despite its rich vascularity and no osteoid formation [12] [13]. GCRGs has benign course, it can be locally aggressive whereas GCT has more malignant course, higher rate of recurrence and is reported to metastasize [14]. Laboratory values are extremely important in case of brown tumours in showing elevated serum calcium, alkaline phosphatase, parathyroid hormone levels and depressed serum phosphate [2] [4]. ABCs are non-neoplastic primary or secondary lesions that most commonly occur in the long bones and vertebral column with involvement of the facial bones being quite rare. Radiographically, they are eccentric, expansile lucencies commonly seen with fluid-fluid levels.

The treatment of GCRG is usually surgical excision or curettage [8]. Surgical excision is recommended over simple curettage because of higher risk of recurrence without complete excision [13] [14]. It may recur after incomplete removal in $10 \%$ to $15 \%$ [8]. Radiation therapy is reserved for inoperative or recurrent cases [13] [14]. Sarcomatous degeneration can occur after radiation, but de novo malignant transformation is not seen [15]. Chuong et al. recommend the use of block resection in aggressive lesion cases that show painful, cortical bone perforation [16]. In our case, surgical excision and additional curettage method were performed due to adherence to orbital periosteum. There was no recurrence seen in 2 years follow-up.

The use of steroid has been reported. It is speculated that the extracellular portion of bone-resorption-mediating lysosomal proteases by giant cells is inhibited by steroids which also induce apoptosis of the osteoclastlike cells [17]. Different studies showed a variable response of patients to calcitonin therapy, intralesional corticosteroids and alpha-IFN administered for aggressive GCRGs seems capable of stopping rapid growth of the lesion and consolidating or even diminishing their size but it is still necessary to use additional surgery to eliminate the lesion. Yoshida et al. have reported that two GCRG patients were treated by curettage followed by adjuvant therapy comprising phenol and ethanol and bone grafting, and no recurrence was seen after this treatment [18].

\section{Conclusion}

This case of giant cell reparative granuloma of nasal cavity is a rare presentation with involvement of maxillary, ethmoidal, frontal sinuses and also orbit on left side. Though it is a benign lesion, it can behave aggressively with erosion of surrounding areas. Because GCRG doesn't show any characteristic features radiologically, biopsies are usually necessary to confirm the diagnosis. Surgical excision is main modality of treatment. Recurrence can occur if incompletely excised. Curettage can also be done to ensure complete removal. Endoscopic removal has advantage of less morbidity and no external scar. Endoscopic removal can be considered for those lesions without any intracranial extension. GCRG can be considered as differential diagnosis for unilateral mass in younger patients presenting with these complaints. Diagnosis is reached through combination of clinical findings, imaging and histopathological examination.

\section{References}

[1] Jaffe, H.L. (1953) Giant-Cell Reparative Granuloma, Traumatic Bone Cyst, and Fibrous (Fibro-Osseous) Dysplasia of the Jawbones. Oral Surgery, Oral Medicine, Oral Pathology, 6, 159-175. http://dx.doi.org/10.1016/0030-4220(53)90151-0

[2] Wiatrak, B.J., Gluckman, J.L., Fabian, R.L. and Wesseler, T.A. (1987) Giant Cell Reparative Granuloma of the Ethmoid Sinus. Otolaryngology—Head and Neck Surgery, 97, 504-509.

[3] Alappat, J.P., Pillai, A.M., Prasanna, D. and Sambasivan, M. (1992) Giant Cell Reparative Granuloma of the Craniofacial Complex: Case Report and Review of the Literature. British Journal of Neurosurgery, 6, 71-74. http://dx.doi.org/10.3109/02688699209002905

[4] Rogers, L.F., Mikhael, M., Christ, M. and Wolff, A. (1984) Case Report 276. Skeletal Radiology, 12, 48-53. http://dx.doi.org/10.1007/BF00373177

[5] Oda, Y., Tsuneyoshi, M. and Shinohara, N. (1992) “Solid” Variant of Aneurismal Bone Cyst (Extragnathic Giant Cell Reparative Granuloma) in the Axial Skeleton and Long Bones: A Study of Its Morphologic Spectrum and Distinction from Allied Giant Cell Lesions. Cancer, 70, 2642-2649.

http://dx.doi.org/10.1002/1097-0142(19921201)70:11<2642::AID-CNCR2820701113>3.0.CO;2-\#

[6] Ilaslan, H., Sundaram, M. and Unni, K.K. (2003) Solid Variant of Aneurismal Bone Cysts in Long Tubular Bones: Gi- 
ant Cell Reparative Granuloma. American Journal of Roentgenology, 180, 1681-1687. http://dx.doi.org/10.2214/ajr.180.6.1801681

[7] Hoopes, P.C., Anderson, R.L. and Blodi, F.C. (1981) Giant Cell (Reparative) Granuloma of the Orbit. Ophthalmology, 88, 1361-1366. http://dx.doi.org/10.1016/S0161-6420(81)34851-9

[8] Gunel, C., Erpek, G. and Meteoglu, I. (2007) Giant Cell Reparative Granuloma in the Hard Palate. International Journal of Pediatric Otorhinolaryngology Extra, 2, 76-79. http://dx.doi.org/10.1016/j.pedex.2007.02.001

[9] Kaffe, I., Ardekian, L., Taicher, S., Littner, M.M. and Buchner, A. (1996) Radiologic Features of Central Giant Cell Granuloma of the Jaws. Oral Surgery, Oral Medicine, Oral Pathology, Oral Radiology, and Endodontics, 81, 720-726. http://dx.doi.org/10.1016/S1079-2104(96)80079-5

[10] Rhea, J.T. and Weber, A.L. (1983) Giant-Cell Granuloma of the Sinuses. Radiology, 147, 135-137. http://dx.doi.org/10.1148/radiology.147.1.6828718

[11] Friedberg, S.A., Eisenstein, R. and Wallner, L.J. (1969) Giant Cell Lesions Involving the Nasal Accessory Sinuses. Laryngoscope, 79, 763-776. http://dx.doi.org/10.1288/00005537-196905000-00001

[12] Lorenzo, J.C. and Dorfman, H.D. (1980) Giant-Cell Reparative Granuloma of Short Tubular Bones of the Hands and Feet. The American Journal of Surgical Pathology, 4, 551-563. http://dx.doi.org/10.1097/00000478-198012000-00006

[13] Nemoto, Y., Inoue, Y., Tashiro, T., et al. (1995) Central Giant Cell Granuloma of the Temporal Bone. American Journal of Neuroradiology, 16, 982-985.

[14] Murphey, M.D., Nomikos, G.C., Flemming, D.J., et al. (2001) From the Archives of AFIP: Imaging of Giant Cell Tumor and Giant Cell Reparative Granuloma of Bone: Radiologic-Pathologic Correlation. Radiographics, 21, 1283-1309. http://dx.doi.org/10.1148/radiographics.21.5.g01se251283

[15] Austin, L.T., Dahlin, D.C. and Royer, R.Q. (1959) Giant Cell Granuloma and Related Conditions Affecting Jaw Bones: An Analysis of 38 Cases. Oral Surgery, Oral Medicine, Oral Pathology, 12, 1285. http://dx.doi.org/10.1016/0030-4220(59)90215-4

[16] Chuong, R., Kaban, L.B., Kozakewich, H. and Perez-Atayde, A. (1986) Central Giant Cell Lesions of the Jaws: A Clinicopathologic Study. Journal of Oral and Maxillofacial Surgery, 44, 708-713. http://dx.doi.org/10.1016/0278-2391(86)90040-6

[17] Theologie-Lygidakis, N., Telona, P., Michail-Strantzia, C., et al. (2011) Treatment of Central Giant-Cell Granulomas of the Jaw Inchildren: Conservative or Radical Surgical Approach? Journal of Cranio-Maxillofacial Surgery, 39, 639644. http://dx.doi.org/10.1016/j.jcms.2010.11.010

[18] Yoshida, T., Sakamoto, A., Tanaka, K., Matsuda, S., Oda, Y. and Iwamoto, Y. (2007) Alternative Surgical Treatment for Giant-Cell Reparative Granuloma in the Metacarpal, Using Phenol and Ethanol Adjuvant Therapy. Journal of Hand Surgery, 32, 887-892. http://dx.doi.org/10.1016/j.jhsa.2007.04.001 
Scientific Research Publishing (SCIRP) is one of the largest Open Access journal publishers. It is currently publishing more than 200 open access, online, peer-reviewed journals covering a wide range of academic disciplines. SCIRP serves the worldwide academic communities and contributes to the progress and application of science with its publication.

Other selected journals from SCIRP are listed as below. Submit your manuscript to us via either submit@scirp.org or Online Submission Portal.
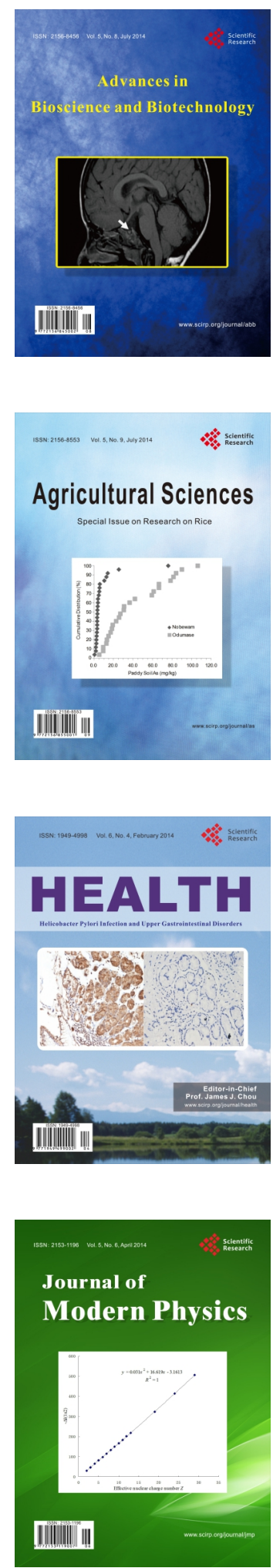
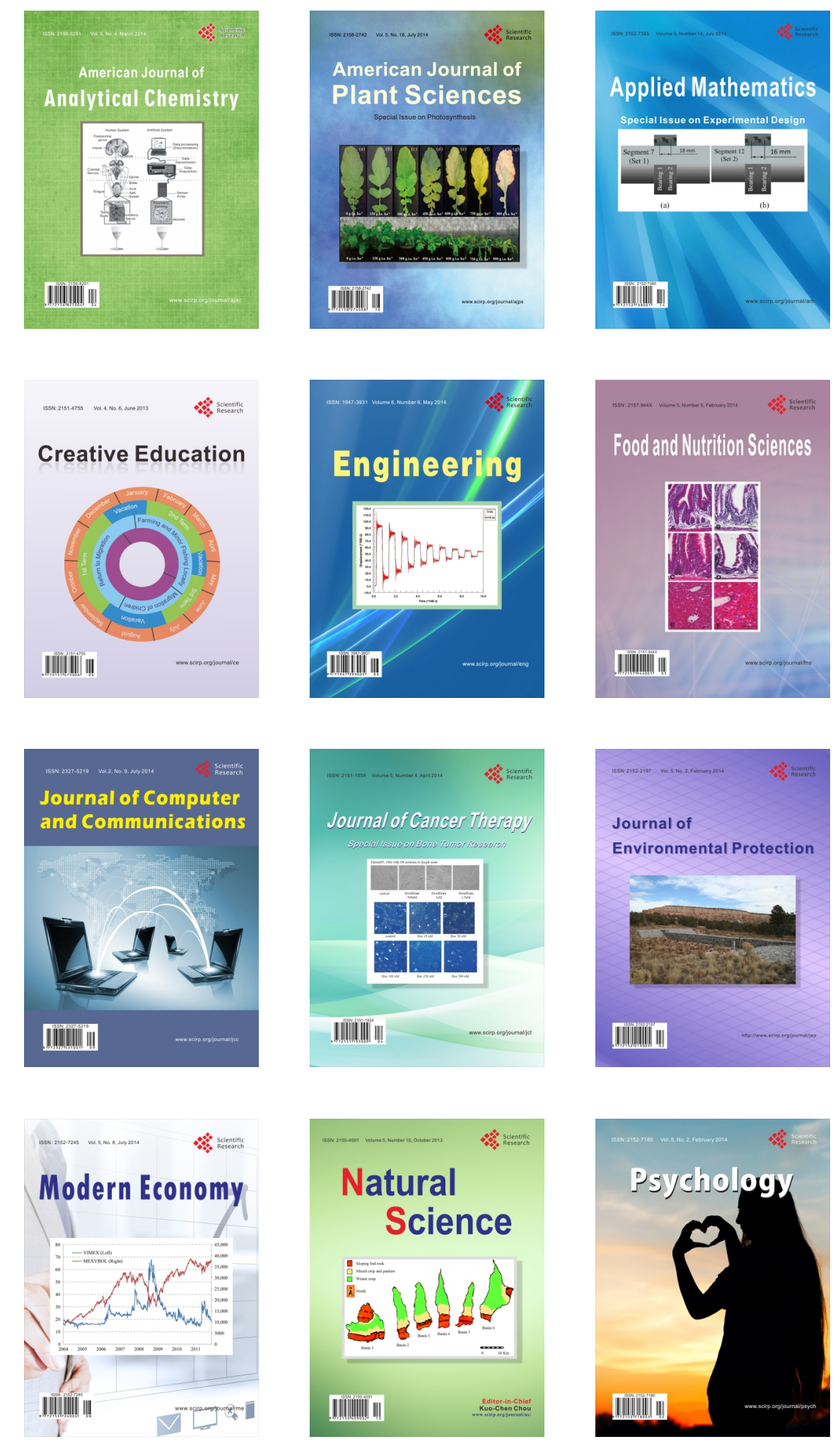